\title{
Interleukin-1 signaling contributes to acute islet compensation
}

\author{
Catherine Hajmrle, Nancy Smith, Aliya F. Spigelman, Xiaoqing Dai, Laura Senior, Austin Bautista, \\ Mourad Ferdaoussi, and Patrick E. MacDonald \\ Department of Pharmacology and Alberta Diabetes Institute, University of Alberta, Edmonton, Alberta, Canada.
}

IL-1 $\beta$ is a well-established inducer of both insulin resistance and impaired pancreatic islet function. Despite this, findings examining IL-1 receptor deficiency or antagonism in in vivo animal models, as well as in clinical studies of type 2 diabetic (T2D) patients, have led to conflicting results, suggesting that the actions of IL-1 $1 \beta$ on glycemic control may be pleiotropic in nature. In the present work, we find that the ability of IL-1 $1 \beta$ to amplify glucose-stimulated insulin secretion from human islets correlates with donor BMI. Islets from obese donors are sensitized to the insulinotropic effects of this cytokine, whereas the stimulatory effects of IL-1 $\beta$ are lost in islets from obese T2D patients, suggesting a role for IL-1 signaling in islet compensation. Indeed, mice deficient in IL-1 receptor type I become glucose intolerant more rapidly than their WT littermates and have impaired secretory responses during the acute stages of inflammatory and metabolic stress induced by LPS and high-fat diet, respectively. IL-1 $\beta$ directly enhances $\beta$ cell insulin secretion by increasing granule docking and soluble $\mathrm{N}$-ethylmaleimide-sensitive factor attachment receptor (SNARE) complex formation at the plasma membrane. Together, our study highlights the importance of IL-1 $\beta$ signaling in islet compensation to metabolic and inflammatory stress.

Conflict of interest: The authors have declared that no conflict of interest exists.

Submitted: January 4, 2016 Accepted: March 3, 2016 Published: April 7, 2016

Reference information: JCI Insight. 2016;1(4):e86055. doi:10.1172/jci.insight.86055.

\section{Introduction}

Activation of the innate immune system by metabolic stress is a prominent mediator of $\beta$ cell failure during type 2 diabetes (T2D) $(1,2)$. The detrimental effects of inflammation are predominantly mediated by the proinflammatory cytokine IL-1 $\beta$. Inhibition of IL- 1 signaling by the endogenous IL-1 receptor antagonist (IL-1Ra) prevents $\beta$ cell cytotoxicity induced by chronic metabolic stress, restoring secretory function in pancreatic islets $(3,4)$. Conversely, prolonged exposure to IL-1 $\beta$, which is elevated in islets of T2D patients $(4,5)$, promotes $\beta$ cell dysfunction $(4,6)$.

Despite the detrimental effects of IL-1 $\beta$ exposure on $\beta$ cells in vitro, circulating levels of IL-1 $\beta$ alone were not associated with increased T2D risk in a large, multicenter cohort (7). Sustained inhibition of IL-1 signaling, induced by a genetic upregulation of IL-1Ra, was also found to have no effect on diabetes risk (8). Therapeutic interventions aimed at reducing IL-1 signaling in patients with T2D or metabolic syndrome have produced conflicting results (9-15), with some studies demonstrating an inability of these therapies to significantly improve glycemic control, despite effectively reducing systemic inflammation (911). Furthermore, inhibition of IL-1 signaling, induced through genetic $\mathrm{KO}$ of the gene encoding the IL-1 receptor type I (IL-1R1) (16) or IL-1 $\beta$ (17), induces glucose intolerance in mice. These findings suggest that the actions of IL- $1 \beta$ on glycemic control may be pleiotropic in nature, with IL-1 signaling exerting both positive and negative effects in vivo.

Beneficial effects of IL-1 $\beta$ on $\beta$ cell function and glycemic control have been reported. Acute infusion of IL-1 $\beta$ induces hypoglycemia (18-20) and increases plasma insulin concentrations (20-22). While the underlying mechanism of action is unknown, the rapid nature of the exposure indicates that the stimulatory effect of IL-1 $\beta$ is not due to proliferative actions (17). In support of this, IL-1 $\beta$ acts directly on $\beta$ cells to potentiate glucose-stimulated insulin secretion from perfused pancreata $(23,24)$, isolated islets $(25-38)$, and purified $\beta$ cells (38). Although several potential mechanisms of IL-1 $\beta$-potentiated insulin secretion have been proposed (37-39), the role of both intracellular $\mathrm{Ca}^{2+}\left(\left[\mathrm{Ca}^{2+}\right]_{i}\right)$ and the amplification pathway in this process remain unclear.

Inflammation is induced rapidly upon exposure to metabolic stress (40), with several reports observing postprandial elevations in inflammatory markers (41-44). Acute hyperglycemia has been shown to increase 
A mouse islets:

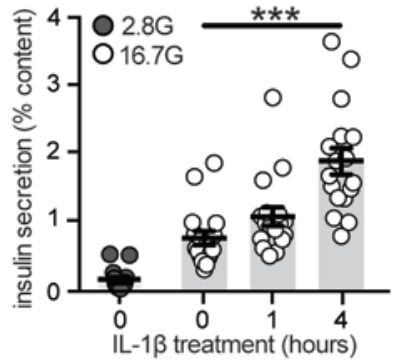

D

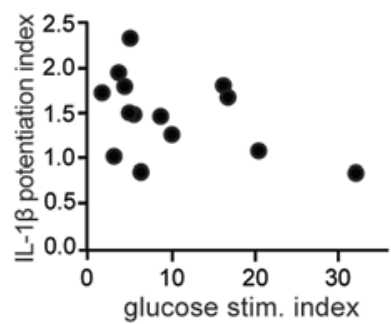

G non-T2D islets:

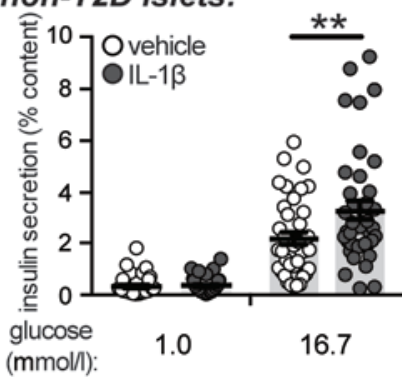

B human islets:

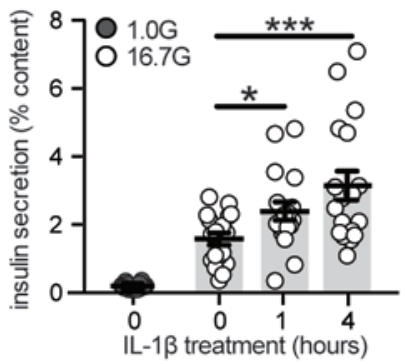

E

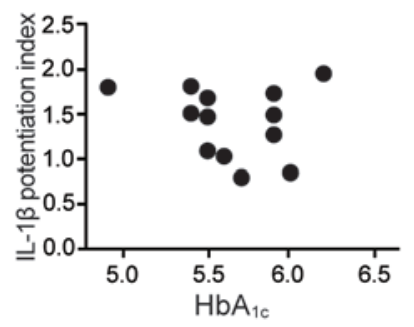

H T2D islets:

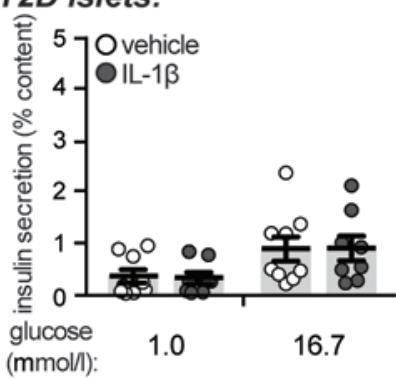

C human islets:

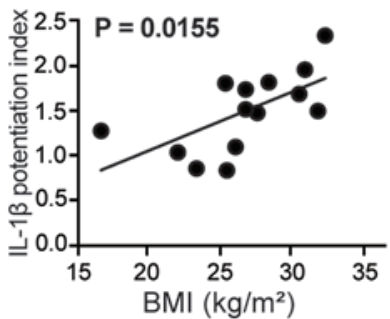

$\mathbf{F}$

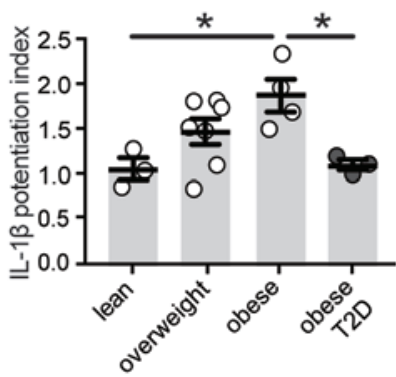

Figure 1. The stimulatory capacity of IL-1 1 is correlated with BMI and is absent in type $\mathbf{2}$ diabetic islets. (A and B) Insulin secretion normalized to percent insulin content from (A) mouse ( $n=15,17,17,17 ; 6$ experiments) or (B) human islets ( $n=18,18,18,18$; 6 donors) following exposure to IL-1 3 (10 ng/ml), as indicated, and stimulated with $1.0(1.0 \mathrm{G}), 2.8(2.8 \mathrm{G})$, or $16.7(16.7 \mathrm{G}) \mathrm{mmol} / \mathrm{l}$ glucose. (C-E) The potentiation index of 1-hour IL-1 $\beta$ treatment plotted against (C) BMI $\left(\mathrm{kg} / \mathrm{m}^{2} ; n=14\right.$ donors), (D) glucose stimulation index ( $n=14$ donors), and (E) glycated hemoglobin ( $\mathrm{HbA}_{1} ; n=13$ donors) in nondiabetic human islet donors. (F) Comparison of IL-1 $\beta$ potentiation index between type 2 diabetic (T2D) and control islets according to BMI tertiles (lean < 25; overweight 25-30; and obese > $\left.35 \mathrm{~kg} / \mathrm{m}^{2}\right)(n=3,7,4,3$ donors). (G and $\mathbf{H})$ Insulin secretion normalized to percent insulin content from (G) nondiabetic $(n=41,36,39,39 ; 14$ donors) or (H) T2D human donors ( $n=9,8,9,8$; 3 donors) treated for 1 hour with vehicle or IL-1 $1(10 \mathrm{ng} / \mathrm{ml})$ and stimulated with either 1.0 or $16.7 \mathrm{mmol} / \mathrm{l}$ glucose. $n$ values correspond to data points from left to right, respectively. Data are mean \pm SEM and were compared with (A, B, G, and $\mathbf{H})$ 2-way ANOVA followed by Tukey post-test, (C-E) Pearson correlation coefficients, or (F) 1-way ANOVA followed by Tukey post-test. ${ }^{*} P<0.05,{ }^{* *} P<0.01,{ }^{* * *} P<0.001$, as indicated. G, glucose.

IL-1 $\beta$ transcript expression in peripheral leukocytes (42). Metabolic stress also induces upregulation of IL-1 $\beta$, with an elevation of the IL-1 $\beta$ target gene, inducible nitric oxide synthase, observed as early as 3 days in white adipose tissue from high fat diet-fed (HFD-fed) mice (40). Furthermore, both high glucose and free fatty acid concentrations induce intraislet production of IL-1 $\beta$ within 4 days of exposure $(4,45)$. That mechanisms have evolved to increase IL-1 $\beta$ expression early in response to metabolic stress suggests an important compensatory role of this cytokine in the acute stages of overnutrition.

This study examined the role of IL-1 signaling in the acute response to metabolic stress and inflammation, as well as the mechanisms underlying IL-1 $\beta$-mediated potentiation of insulin secretion. IL- $1 \beta$ was shown to potentiate insulin secretion from pancreatic $\beta$ cells by increasing exocytosis subsequent to enhanced insulin granule docking at the plasma membrane. While the stimulatory efficacy of IL-1 $\beta$ was found to positively correlate with BMI in nondiabetic human islets, IL-1 $\beta$ was unable to potentiate glucosestimulated insulin secretion in islets from obese T2D donors. Genetic KO of the gene encoding the IL-1R1, Il1r1, exacerbated glucose intolerance in mice following a short-term exposure to HFD and reduced glucose sensitivity induced by acute LPS injection. The impairment in glucose tolerance observed in both HFD- 


\section{A mouse $\beta$-cells:}
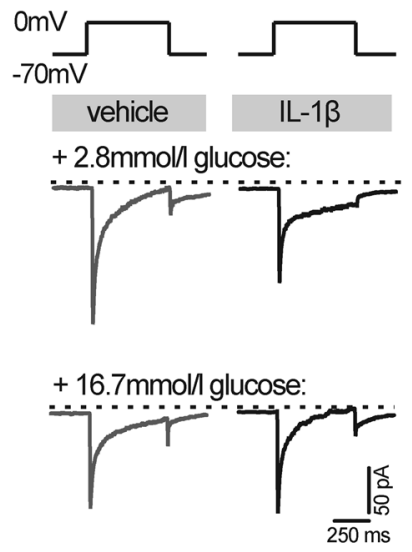

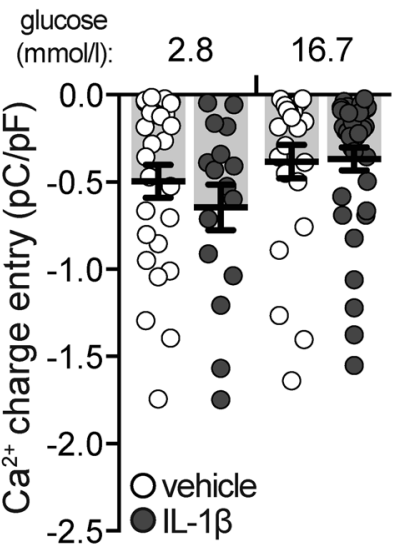

\section{B mouse islets:}
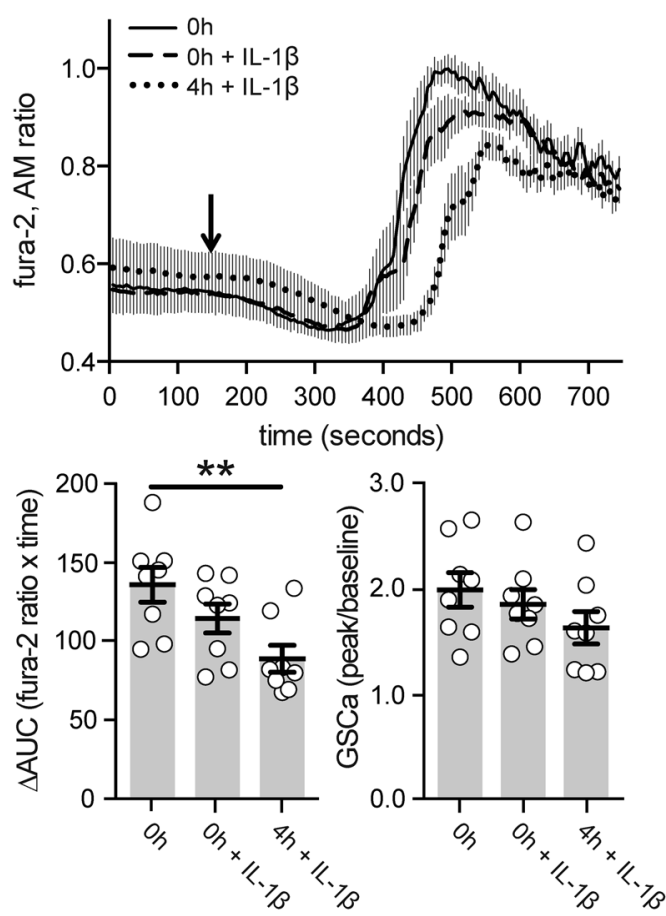

Figure 2. The stimulatory effect of IL-1 $\beta$ is downstream of intracellular $\mathrm{Ca}^{2+}$. (A) Representative (left) and quantified (right) traces of Ca ${ }^{2+}$ currents obtained by a single depolarization from -70 to $0 \mathrm{mV}$ in dispersed mouse $\beta$ cells treated with vehicle or IL-1 $\beta$ ( $10 \mathrm{ng} / \mathrm{ml}$ ) in the presence of either 2.8 or 16.7 $\mathrm{mmol} / \mathrm{I}$ glucose $\left(n=27,16,24,36\right.$ cells; 3 experiments). (B) Responses in intracellular $\mathrm{Ca}^{2+}\left(\left[\mathrm{Ca}^{2+}\right]_{\mathrm{i}}\right)$ from mouse islets following preincubation with IL-1 $\beta$ (10 $\mathrm{ng} / \mathrm{ml})$ for 4 hours $(4 \mathrm{~h}+\mathrm{IL}-1 \beta)$ or with acute IL- $\beta$ treatment $(0 \mathrm{~h}+\mathrm{IL}-1 \beta)$ in conjunction with glucose stimulation (arrow; top). Change in area under the curve $(\triangle \mathrm{AUC})$ of $\left[\mathrm{Ca}^{2+}\right]_{i}$ responses (bottom left) $\left(n=8,8,8 \text { islets; } 3 \text { experiments) and fold increase in glucose-stimulated [Ca }{ }^{2+}\right]_{\mathrm{i}}$ (CSCa) responses (bottom right) $(n=8,8,8$ islets; 3 experiments). $n$ values correspond to data points from left to right, respectively. Data are mean \pm SEM and were compared with (A) 2-way or (B) 1-way ANOVA followed by (A and $\mathbf{B}$ ) Tukey post-test. ${ }^{*} P<0.05,{ }^{* *} P<0.01$, as indicated.

and LPS-treated mice was associated with the reduced ability of glucose to stimulate insulin secretion in vivo, demonstrating a beneficial role of IL-1 signaling in acute islet compensation to metabolic stress.

\section{Results}

The stimulatory capacity of $I L-1 \beta$ is positively correlated with BMI of nondiabetic donors but is absent in T2D islets. Consistent with previous reports (25-38), acute exposure to IL-1 $\beta(10 \mathrm{ng} / \mathrm{ml})$ enhanced glucose-stimulated insulin secretion from mouse (Figure 1A) and human (Figure 1B) islets. IL-1 $\beta$ had no effect on islet insulin content and did not affect secretion at low glucose (data not shown). IL-1 signaling was not required for optimal secretory function under normal conditions, as no significant differences in $\beta$ cell $\mathrm{Ca}^{2+}$ currents, $\left[\mathrm{Ca}^{2+}\right]_{\mathrm{i}}$ handling, granule trafficking, exocytosis, or glucose-stimulated insulin secretion were observed in mice deficient in Illr1 (Supplemental Figures 1 and 2; supplemental material available online with this article; doi:10.1172/jci.insight.86055DS1).

Substantial variability in the ability of IL-1 $\beta$ to potentiate glucose-stimulated insulin secretion between individual human islet preparations was observed (Supplemental Table 1), prompting the examination of associations between the insulinotropic capacity of IL-1 $\beta$ and several anthropometric and metabolic variables. The potentiation index of IL-1 $\beta$, defined as the ratio of insulin secretion induced by high glucose in the presence of IL-1 $\beta$ to insulin secretion induced by high glucose alone, positively correlated to BMI in nondiabetic islets $(r=0.63$; Figure $1 C)$. The ability of IL-1 $\beta$ to potentiate glucose-stimulated insulin secretion was not associated with the stimulation index of glucose $(r=-0.42$; Figure $1 D)$, glycated hemoglobin $\left(\mathrm{HbA}_{1 \mathrm{c}} ; \mathrm{r}=-0.17\right.$; Figure $\left.1 \mathrm{E}\right)$, or age $(\mathrm{r}=0.25$; data not shown). The stimulatory capacity of IL- $1 \beta$ was also assessed in islets from T2D donors. A significant difference in the potentiation index of IL- $1 \beta$ between obese nondiabetic and obese T2D donors was observed (Figure 1F). While mean BMI was higher in the T2D donors than the nondiabetic donors (Supplemental Table 2), BMI was no longer correlated with the potentiation index of IL-1 $\beta$ when diabetic donors were included in the analysis $(P=0.73, \mathrm{r}=0.09$; data not 
A human $\beta$-cells:

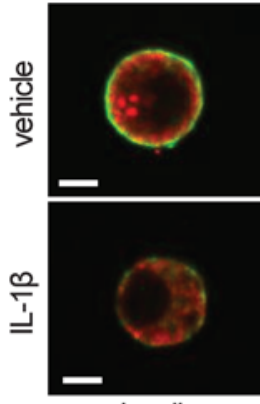

insulin

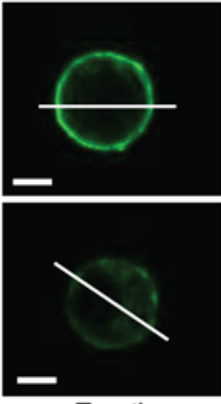

F-actin

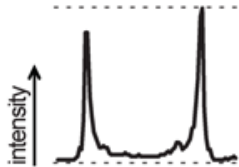

vehicle

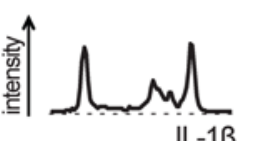

IL $-1 \beta$

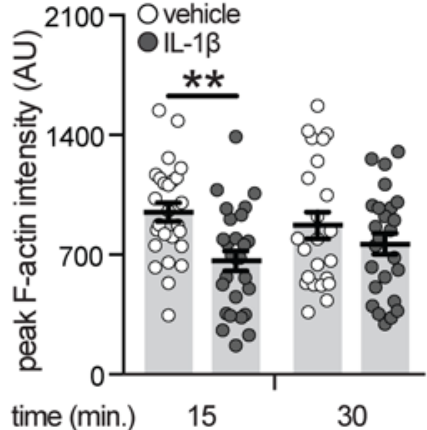

B

mouse $\beta$-cells:

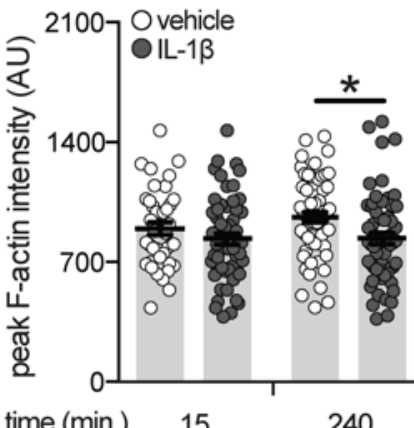

\section{C mouse islets:}

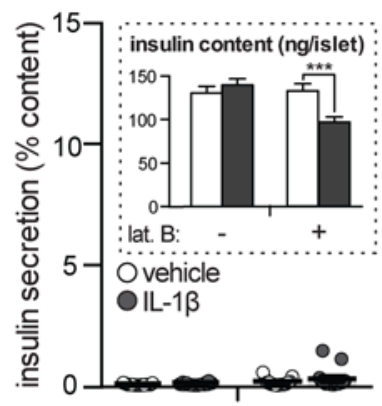

lat. $B(\mu \mathrm{mol} / \mathrm{L})$
10

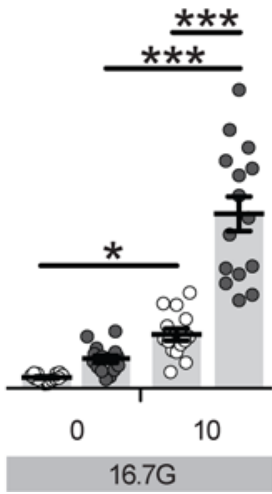

\section{D human islets:}

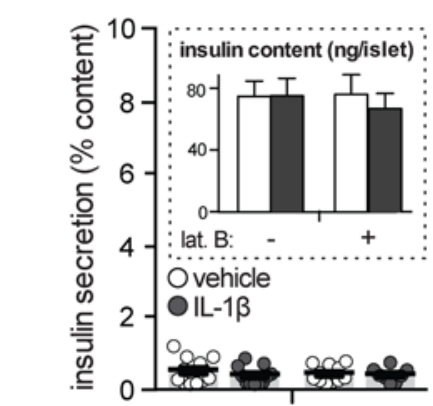

lat. $B(\mu \mathrm{mol} / \mathrm{L})$ :
10

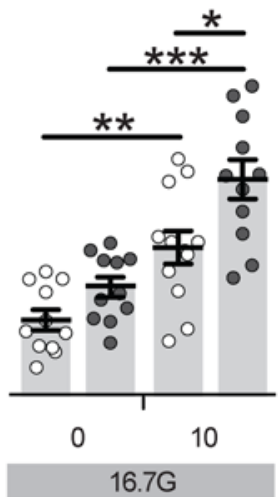

Figure 3. Acute treatment with IL-1 $\beta$ induces filamentous-actin depolymerization. (A) Dispersed human $\beta$ cells treated with vehicle or IL-1 $\beta$ (10 ng/mI) in the presence of $2.8 \mathrm{mmol} / \mathrm{l}$ glucose, as indicated, and stained for insulin (red) or filamentous actin (F-actin; green). Representative images (left; 15-minute treatment), example line scan analysis (middle), and quantification of average peak F-actin intensities (right) as arbitrary units (AU) are shown ( $n=26$, 27, 23, 25 cells; 4 donors). Scale bars represent 5 microns. (B) As in A but with dispersed mouse $\beta$ cells ( $n=39,58,58,60$ cells; 3 experiments). (C) Insulin secretion normalized to percent insulin content from mouse islets treated with IL-1 $\beta$ (10 ng/ml; 4 hours) and/or latrunculin B (lat. B; $10 \mu$ mol/I; 1 hour) and stimulated with 2.8 (2.8 G) or 16.7 (16.7 G) mmol/I glucose ( $n=15,14,15,15,14,15,14,15$; 5 experiments). Insulin contents are shown (inset). (D) As in C but with human islets treated with IL-1 $\beta$ ( 2 hours) and lat. B (1 hour) ( $n=12,11,11,8,11,11,12,11 ; 4$ donors) and stimulated with 1.0 (1.0 $\mathrm{C}$ ) or 16.7 ( $16.7 \mathrm{G}$ ) mmol/I glucose. $n$ values correspond to data points from left to right, respectively. Data are mean \pm SEM and were compared with 2 -way ANOVA followed by Tukey post-test. ${ }^{*} P<0.05,{ }^{* *} P<0.01$, and ${ }^{* * *} P<0.001$, as indicated. G, glucose.

shown). Contrary to the significant insulinotropic effect of IL-1 $\beta$ observed in nondiabetic islets (Figure $1, \mathrm{~B}$ and G), IL-1 $\beta$ did not potentiate glucose-stimulated insulin secretion from obese, T2D donors (Figure $1 \mathrm{H}$ ).

The stimulatory effect of $\mathrm{IL}-1 \beta$ is downstream of $\left[\mathrm{Ca}^{2+}\right]_{i}$. One of several proposed mechanisms underlying the IL-1 $\beta$-mediated potentiation of insulin secretion is an $\mathrm{IL}-1 \beta$-induced rise in $\left[\mathrm{Ca}^{2+}\right]_{\mathrm{i}}(32,38,39)$. While it is known that the insulinotropic effect of $\mathrm{IL}-1 \beta$ requires $\mathrm{Ca}^{2+}$ flux into the $\beta$ cell $(31,34)$, whether the stimulatory effects of IL-1 $\beta$ are due to an increase in $\left[\mathrm{Ca}^{2+}\right]_{\mathrm{i}}$ is still debated $(29,30,32,34,38)$. To provide further insight into the mechanism of IL-1 $\beta$-stimulated insulin release, $\mathrm{Ca}^{2+}$ currents and $\left[\mathrm{Ca}^{2+}\right]_{i}$ were measured following treatment with IL-1 $\beta$. Acute treatment of isolated mouse $\beta$ cells with IL-1 $\beta(10 \mathrm{ng} / \mathrm{ml}$; described in Methods) did not affect $\mathrm{Ca}^{2+}$ currents under low or high glucose conditions (Figure 2A) and did not augment the $\left[\mathrm{Ca}^{2+}\right]_{\mathrm{i}}$ response in intact mouse islets (Figure $2 \mathrm{~B}$ ). Rather, a 4-hour pretreatment of mouse islets with IL-1 $\beta(10 \mathrm{ng} / \mathrm{ml} ; 4 \mathrm{~h}+\mathrm{IL}-1 \beta)$ caused a slight yet significant impairment in glucose-stimulated $\left[\mathrm{Ca}^{2+}\right]_{\mathrm{i}}$ handling (Figure $2 \mathrm{~B}$ ), likely an early manifestation of the impairment in $\left[\mathrm{Ca}^{2+}\right]_{\mathrm{i}}$ that has been shown to occur following overnight exposure to IL-1 $\beta$ treatment (46), indicating that the stimulatory effect of IL- $1 \beta$ is downstream of $\left[\mathrm{Ca}^{2+}\right]_{i}$ entry.

Acute treatment with IL-1 $\beta$ induced filamentous-actin depolymerization in human $\beta$ cells. In $\beta$ cells, filamentous actin (F-actin) forms a cortical web below the plasma membrane, functioning as a barrier between granules and the plasma membrane. Disruption of the cortical F-actin barrier enhances insulin secretion secondary to increased insulin granule access to the plasma membrane $(47,48)$. Findings that acute exposure to IL- $1 \beta$ 
A mouse $\beta$-cells:

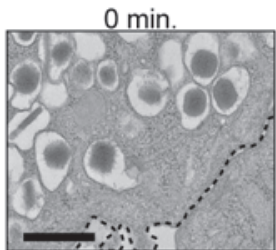

$15 \min . \mathrm{IL}-1 \beta$

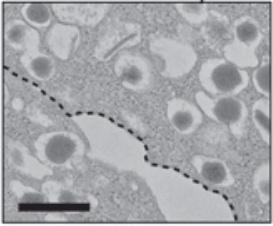

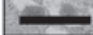

B mouse $\beta$-cells:

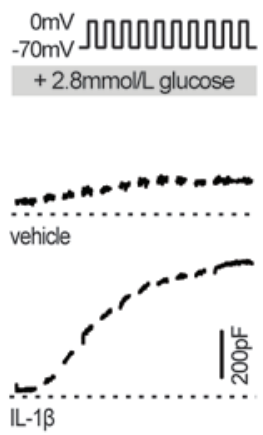

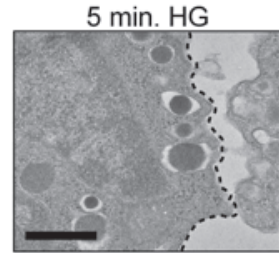

$30 \min . \mathrm{IL}-1 \beta$
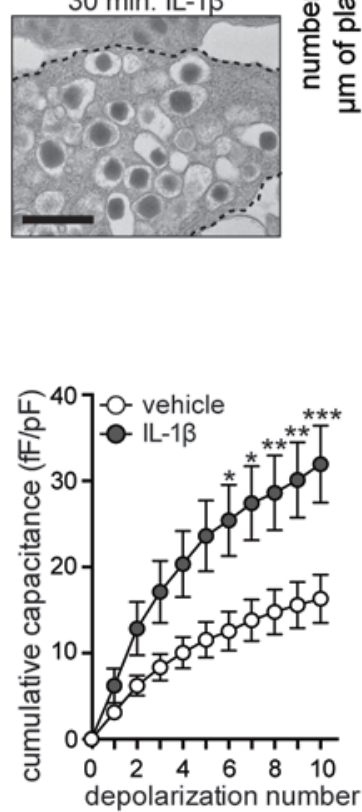

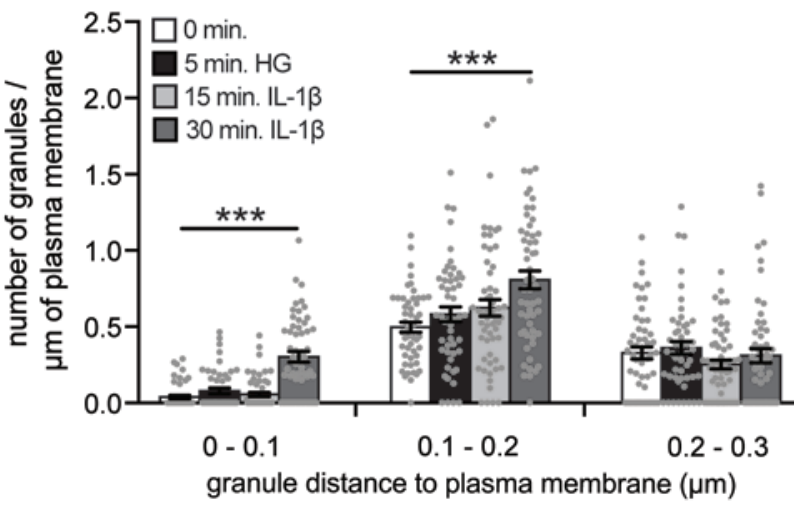

C INS-1 cells:

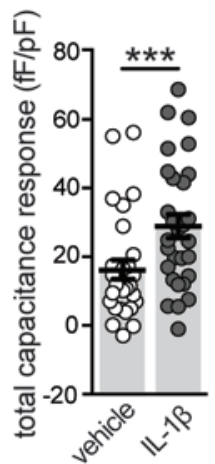

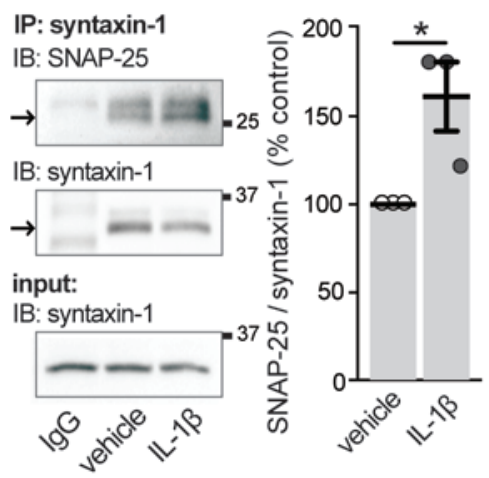

Figure 4. Acute treatment with IL-1 $\beta$ increases the number of docked insulin granules. (A) Representative electron micrographs of mouse $\beta$ cells treated with vehicle or IL-1 $\beta(10 \mathrm{ng} / \mathrm{ml})$, as indicated (left), and quantification of the number of granules per micron of plasma membrane (right) ( $n=51$, $50,56,55,51,51,57,55,52,50,57,55$ cells; 3 experiments). Experiments were performed in $2.8 \mathrm{mmol} / \mathrm{l}$ glucose, unless otherwise indicated (HG $=16.7$ $\mathrm{mmol} / \mathrm{l}$ glucose). Black dashed line indicates plasma membrane. Scale bar represents $500 \mathrm{~nm}$. (B) Exocytosis responses of single mouse $\beta$ cells treated with IL-1 $1(10 \mathrm{ng} / \mathrm{ml})$ measured as an increase in cell membrane capacitance during a train of membrane depolarizations from -70 to $0 \mathrm{mV}$ (left). Average capacitance response to each step-wise depolarization (middle) and total capacitance responses (right) ( $n=29,29$ cells; 3 experiments). (C) Synaptosomal-associated protein 25 (SNAP-25)/syntaxin-1 complex formation in INS 832/13 cells treated with vehicle or IL-1 13 (10 ng/ml; 30 minutes) assessed by IP of IgG or syntaxin-1 and IB of SNAP-25 or syntaxin-1 (left). Quantification by densitometry relative to vehicle-treated control is shown (right) ( $n=$ 3, 3; 3 experiments). $n$ values correspond to data points from left to right, respectively. Data are mean \pm SEM and were compared with (A) 2 -way ANOVA followed by Tukey post-test, (B) repeated-measures ANOVA followed by Sidak post-test, or (C) a 2-tailed Student's $t$ test. ${ }^{*} P<0.05$, ${ }^{* * *} P<0.001$ versus vehicle-treated control. HG, high glucose.

alters cytoskeletal organization in rat $\beta$ cells (38) suggests that IL-1 $\beta$-induced effects on actin remodeling may underlie its stimulatory effects. Treatment with IL-1 $\beta(10 \mathrm{ng} / \mathrm{ml})$ induced F-actin depolymerization in human (Figure 3A) and mouse (Figure 3B) $\beta$ cells. This process was independent of glucose stimulation, as experiments were performed in nonstimulatory glucose concentrations $(2.8 \mathrm{mmol} / \mathrm{l})$. Indeed, while IL- $1 \beta$ enhances insulin secretion only in the presence of stimulatory glucose, cytoskeletal remodeling induced by IL-1 $\beta$ has been observed in both low- and high-glucose conditions in rat $\beta$ cells (38).

To determine if the potentiation of glucose-stimulated insulin secretion by IL- $1 \beta$ extends beyond its ability to depolymerize F-actin, mouse and human islets were preincubated with IL-1 $\beta(10 \mathrm{ng} / \mathrm{ml} ; 4$ and 1 hours, respectively) and treated with the potent F-actin depolymerizing agent, latrunculin B (10 $\mu$ mol/1; ref. 47). IL-1 $\beta$ enhanced latrunculin B-potentiated glucose-stimulated insulin secretion from mouse (Figure 3C) and human (Figure 3D) islets, indicating that IL-1 $\beta$ is capable of enhancing glucose-stimulated insulin secretion through an $\mathrm{F}$-actin-independent mechanism. While a modest yet significant reduction in insulin content was observed in mouse islets treated with IL-1 $\beta$ and latrunculin B (Figure 3C), similar effects on insulin release were observed when secretion was normalized per islet rather than to insulin content (data not shown). 
A

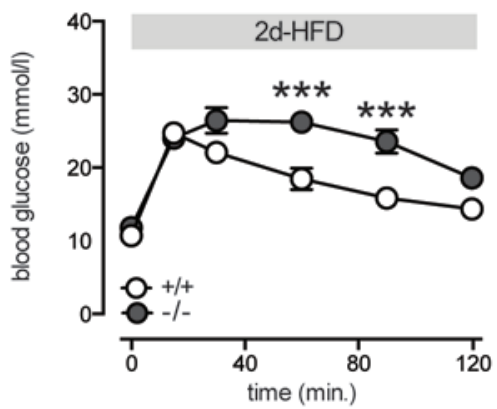

B

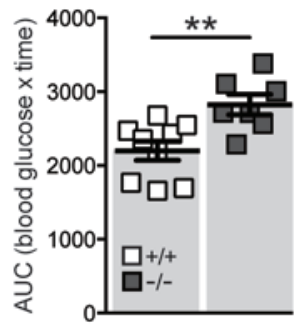

C

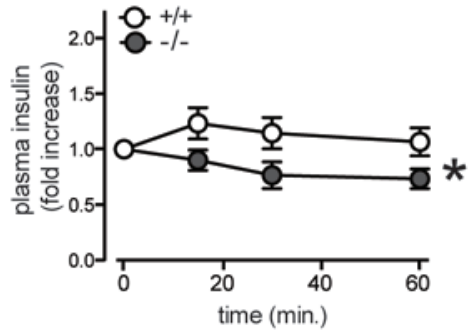

D

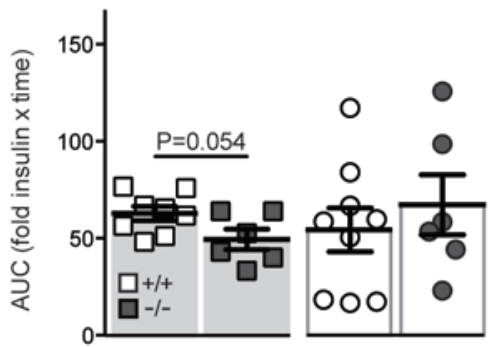

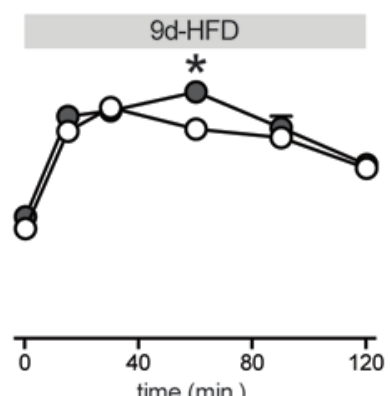
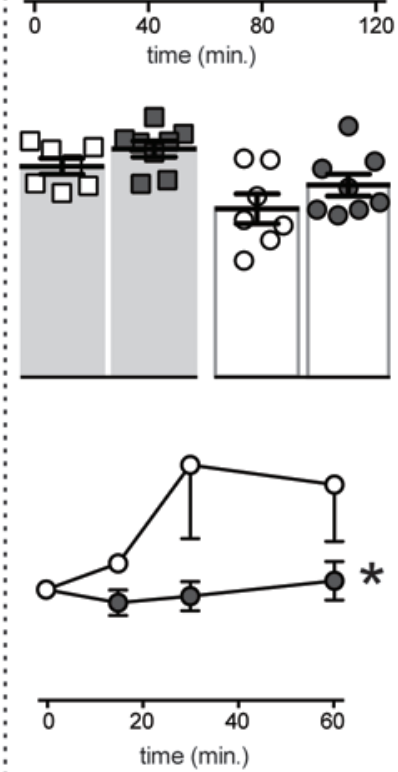

$P=0.059$

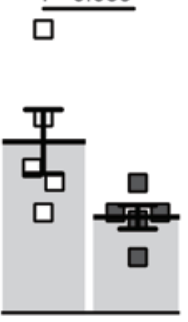

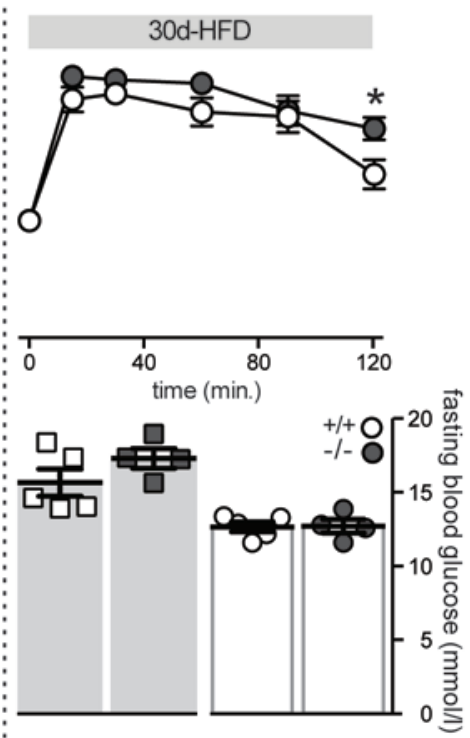
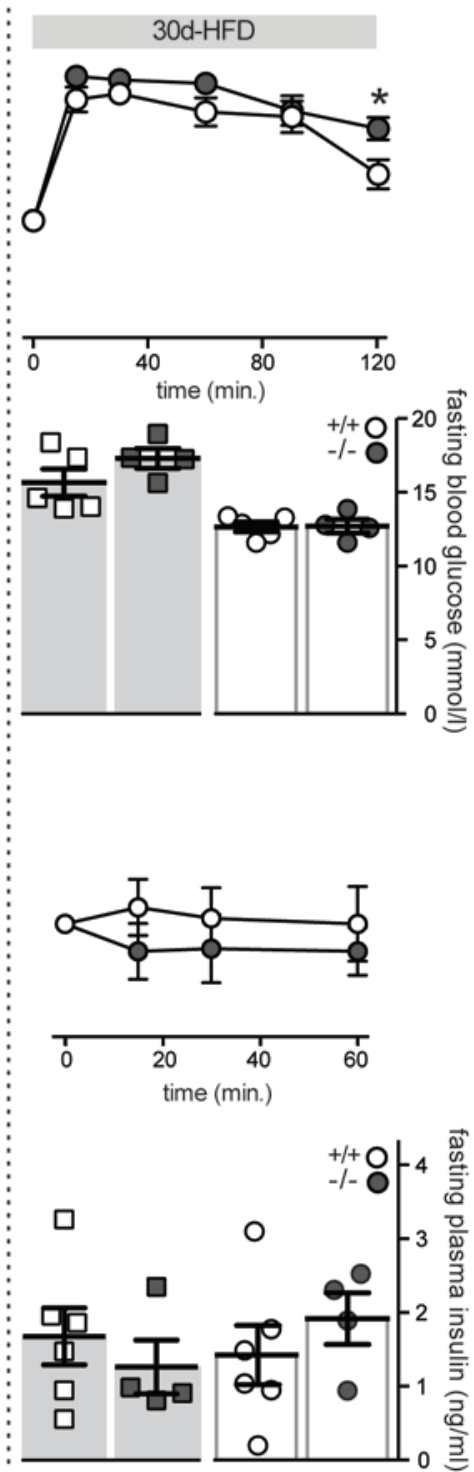

Figure 5. Impaired glucose tolerance and insulin secretory response in I/1r1-KO mice fed a short-term high fat diet. WT (+/+) and /I1r1-KO (-/-) mice were fed a high fat diet (HFD) for 2 (2d), 9 (9d), or 30 (30d) days. (A) Blood glucose measurements following i.p. injection of glucose, subsequent to a 3-hour fast, from WT and KO mice ( $n=9,7 ; n=7,8 ; n=5,4$ mice). (B) Area under the curve (AUC) for glucose tolerance tests in A indicated by squares ( $n=9$, 7; $n=7,8 ; n=5,4$ mice), and fasting blood glucose concentrations in WT and KO mice following a 3-hour fast, indicated by circles $(n=9,7 ; n=7,8 ; n=5,4$ mice). (C) Fold increase in plasma insulin concentrations following i.p. injection of glucose, subsequent to a 3-hour fast, in WT and KO mice ( $n=9,6 ; n=5$, 5; $n=6,4$ mice). (D) AUC for plasma insulin in C indicated by squares $(n=8,6, n=5,5 ; n=6,4$ mice), and fasting plasma insulin concentrations in WT and KO mice following a 3-hour fast, indicated by circles $(n=9,6, n=5,5 ; n=6,4$ mice). $n$ values correspond to data points from left to right and to 2-, 9-, and 30-day graphs, respectively. Data are mean \pm SEM and were compared with (B and $\mathbf{D}$ ) a 2-tailed Student's $t$-test or (A and C) repeated-measures ANOVA followed by (A) Sidak post-test. ${ }^{*} P<0.05,{ }^{* *} P<0.01,{ }^{* *} P<0.001$ versus WT controls or as indicated.

Acute treatment with $I L-1 \beta$ increases the number of docked insulin granules. A lack of effect of IL-1 $\beta$ on $\left[\mathrm{Ca}^{2+}\right]_{\mathrm{i}}$ response suggests a role for IL-1 $\beta$ in regulating downstream events in insulin secretion. $\mathrm{Ca}^{2+}$ triggers insulin release from the pancreatic $\beta$ cell through a regulated secretory pathway that depends on the recruitment, docking, and fusion of insulin granules to the plasma membrane. This process is facilitated by the formation of soluble N-ethylmaleimide-sensitive factor attachment receptor (SNARE) protein complexes, which are known mediators of regulated $\beta$ cell exocytosis (49). Distance measurements between dense core granules and plasma membranes in electron micrographs of $\beta$ cells were used to assess insulin granule trafficking. Granules whose centers are located within $200 \mathrm{~nm}$ of the plasma membrane were considered docked (50-52). A 30-minute exposure to IL-1 $\beta(10 \mathrm{ng} / \mathrm{ml})$ increased the number of granules less than $100 \mathrm{~nm}$ and within $100-200 \mathrm{~nm}$ of the plasma membrane in mouse $\beta$ cells, where the numbers of granules 


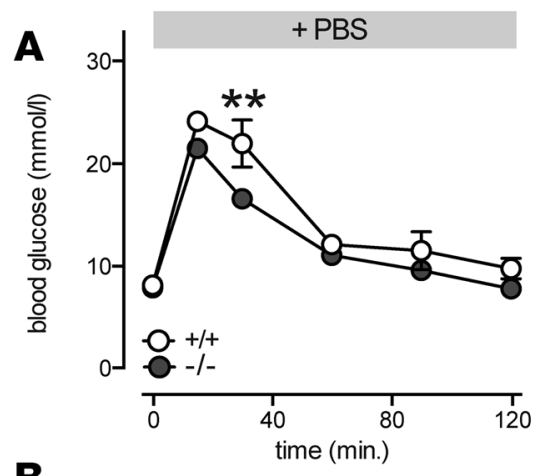

B
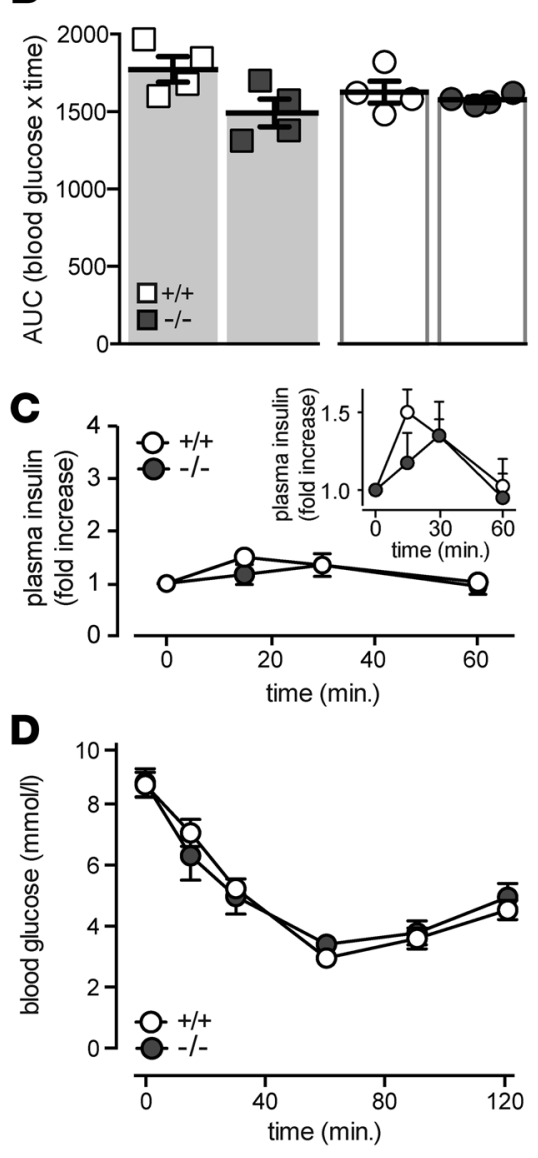

Figure 6. LPS-induced potentiation of insulin secretion is mediated by IL-1 receptor type $\mathrm{I}$. (A) Blood glucose measurements following i.p. glucose injections from WT $(+/+)$ and $/ 11 \mathrm{r1}-\mathrm{KO}(-/-)$ mice treated with LPS $(2 \mathrm{mg} / \mathrm{kg})$ or PBS ( $n=4,4 ; n=4,5$ mice) and fasted for 6 hours. (B) Area under the curve (AUC) for glucose tolerance tests in A indicated by squares ( $n=4,4 ; n=4,5$ mice), and fasting blood glucose concentrations in WT and $\mathrm{KO}$ mice following a 6-hour fast, indicated by circles ( $n=4,4 ; n=4,5$ mice). (C) Fold increase in plasma insulin concentrations following i.p. injection of glucose, subsequent to a 6-hour fast and treatment with LPS or PBS, in WT and KO mice $(n=4$, $4 ; n=3,5$ mice). Comparison of secretory response in PBStreated WT and KO mice (inset; $n=4,4$ mice). (D) Blood glucose measurements following i.p. insulin injections, subsequent to a 6-hour fast, from WT $(+/+)$ and I/1r1-KO $(-/-)$ mice treated with LPS or PBS $(n=4,4 ; n=3,4$ mice). $n$ values correspond to data points from left to right, respectively. Data are mean \pm SEM and were compared with $(\mathbf{A}, \mathbf{C}$, and $\mathbf{D})$ repeated-measures ANOVA followed by Tukey post-test or (B) a 2-tailed Student's $t$-test. ${ }^{*} P<0.05$, ${ }^{*} P<0.01,{ }^{* * *} P<0.001$ versus WT controls.

within 200-300 $\mathrm{nm}$ of the plasma membrane remained unchanged (Figure 4A). Consistent with increased granule docking, acute treatment with IL-1 $\beta(10 \mathrm{ng} / \mathrm{ml})$ also increased depolarization-induced exocytosis from dispersed mouse $\beta$ cells (Figure 4B) and enhanced synaptosomal-associated protein 25 (SNAP25)/ syntaxin-1 SNARE complex formation in INS 832/13 cells (Figure 4C).

Illr1 deficiency impairs glycemic control and reduces in vivo insulin secretory response under conditions of acute inflammatory and short-term metabolic stress. $\beta$ cell compensation in response to metabolic stress is required for the maintenance of normoglycemia $(1,53)$. In rodents, $\beta$ cell compensation upon overnutrition occurs rapidly, with adaptations reported as early as 3 days after HFD (54). Given that this acute adaptation occurs concomitantly with both increases in systemic (40) and intraislet inflammation (45), the role of IL-1R1 signaling in acute islet compensation to metabolic stress was examined. Mice deficient in Il1r1 (Supplemental Figure 1A) were fed a HFD for 2, 9, or 30 days. Il1r1-KO mice had impaired plasma glucose tolerance following i.p. injection of glucose after 2 days of HFD (Figure 5, A and B, left). Mild glucose intolerance was also observed in $\mathrm{KO}$ mice at 9 (Figure 5, A and B, middle) and 30 (Figure 5, A and B, right) days after HFD. The glucose intolerance induced by Il1r1 deficiency following 2 (Figure 5, C and D, left) and 9 (Figure 5, C 
and $\mathrm{D}$, middle) days after HFD was associated with a reduction in the plasma insulin response to glucose, suggestive of impaired $\beta$ cell function. Consistent with the acute insulinotropic effect of IL-1 $\beta$, impaired insulin secretory responses were no longer apparent in Il1r1-deficient mice after 30 days of HFD (Figure $5 \mathrm{C}$ ). No differences in fasting blood glucose (Figure 5B), fasting plasma insulin (Figure 5D), or weight (data not shown) at 2, 9, or 30 days were observed in these 10- to 14-week-old mice.

A positive role for IL-1 signaling in acute compensation to inflammatory stress was confirmed in mice injected with the proinflammatory endotoxin LPS. Consistent with previous reports (18), LPS injection (2 $\mathrm{mg} / \mathrm{kg}$ ) enhanced glucose tolerance in control mice (Figure 6A) by increasing insulin secretion (Figure 6C). The increase in glucose tolerance following LPS injection was reduced in mice lacking Illr1 (Figure 6, A and B). This was not attributable to changes in insulin tolerance (Figure 6D), but rather to enhanced $\beta$ cell secretory function, as the insulin secretory response induced by LPS was absent in Il1r1-deficient mice (Figure 6B). Despite a blunted LPS-enhanced secretory response, normal glucose tolerance was not restored in Il1r1-deficient mice (Figure 6A), indicating the presence of IL-1R1- and $\beta$ cell-independent effects of acute inflammation on glucose tolerance. Consistent with this, elevated fasting blood glucose levels in LPS treated Il1r1-KO mice were not associated with decreases in fasting plasma insulin (data not shown). No differences in body weight in these mice were observed (data not shown).

Consistent with previous reports (16), Illr1-KO mice were characterized by mature-onset obesity. At 9 months of age, both Illr1-heterozygous $(36.4 \pm 0.73 \mathrm{~g} ; n=5$ mice; $P<0.01)$ and $\mathrm{KO}$ mice $(35.8 \pm 1.23 \mathrm{~g}$; $n=5$ mice; $P<0.05)$ had increased body mass compared with their littermate controls $(32.0 \pm 1.53 \mathrm{~g} ; n=$ 4 mice). Previous reports have observed a mild impairment in glucose tolerance in Illr1-deficient mice (16). In the present study, no significant differences in glucose or insulin tolerance were observed in unstimulated Il1r1-KO mice compared with littermate controls (Supplemental Figure 3). These inconsistencies are likely due to differences in experimental protocols, where previous glucose measurements were obtained from nonfasted mice following i.v. injection of glucose (16). In the present study, glucose measurements were obtained from fasted mice following an i.p. injection of glucose. The experimental protocol in the previous study resulted in a much larger peak in blood glucose ( $\sim 35 \mathrm{mmol} / 1$ glucose; ref. 16) compared with the peak obtained with the present protocol ( $25 \mathrm{mmol} / 1$; Supplemental Figure 3$)$. Consistent with a role of IL-1 signaling in acute islet compensation to metabolic stress, glucose intolerance was observed in Il1r1deficient mice following an elevated bolus glucose peak (16) but was absent in Il1r1-deficient mice following a more moderate glucose load.

\section{Discussion}

Immunomodulation of metabolism is regarded as an unfavorable consequence of overnutrition that results in metabolic dysfunction $(1,2,55)$. Inflammation, however, is primarily an acute repair mechanism functioning to preserve homeostasis in response to external stress (56). The acute roles of inflammation on metabolic function, particularly in the context of metabolic stress, remain relatively unknown. The aim of this study was to explore roles of the proinflammatory cytokine IL-1 $\beta$ and its receptor, IL-1R1, on $\beta$ cell function and glucose homeostasis. Here, we provide new insights into the mechanism regulating IL-1 $\beta$ mediated potentiation of insulin secretion and identify IL-1 signaling as a positive regulator of glycemic control in the acute stages of inflammatory and metabolic stress.

$\beta$ cells undergo both structural and functional changes to compensate for the increased insulin demand that is characteristic of obesity (53). Several mechanisms are known to mediate $\beta$ cell adaptation, ranging from increased $\beta$ cell proliferation (54) and mass (57) to enhanced $\beta$ cell secretory function (58) and sensitivity to insulinotropic stimuli (59). Here, we find that the magnitude of IL-1 $\beta$ potentiation of glucosestimulated insulin secretion is positively correlated with human donor BMI, where islets from lean human donors have minimal responses to IL-1 $\beta$. Conversely, IL-1 $\beta$ potentiates glucose-stimulated insulin secretion by almost 2-fold in islets from obese donors, indicating an obesity-associated sensitization of islets to the stimulatory effects of IL-1 $\beta$. IL-1 $\beta$ levels are elevated in obese patients $(60,61)$; are increased following acute, postprandial hyperglycemia (42); and are upregulated in islets following a 4-day exposure to high glucose or free fatty acids $(4,45)$. A sensitization to the insulinotropic effects of this cytokine may represent a compensatory mechanism to metabolic stress. Indeed, in our hands, while IL-1 signaling was not required for optimal glucose homeostasis under physiological conditions, this emerged as a regulator of glucose tolerance following exposure to acute metabolic stress. This is consistent with findings demonstrating the sensitization of islets from obese Zucker fatty rats to the insulinotropic effect of palmitate and glucagon- 
like peptide-1 (59) - a phenomenon that is absent in Zucker lean control rats and that promotes the hyperinsulinemia required to compensate for the insulin-resistance characteristic of these animals.

A critical step in the progression to overt diabetes is the maladaptation of $\beta$ cells to metabolic stress. When $\beta$ cell compensation for insulin resistance ceases, hyperglycemia develops and T2D prevails $(1,53)$. Here, we find the stimulatory potential of IL-1 $\beta$ was lost in islets from obese T2D donors, indicative of impaired or failed $\beta$ cell adaptation in these patients. Where $\beta$ cells from obese individuals with normal glucose tolerance had a heightened sensitivity to the insulinotropic effects of IL-1 $\beta, \beta$ cells from obese T2D donors were unresponsive.

A causal association between IL-1 signaling and islet compensation to acute inflammatory and metabolic stress was identified in the present study. Transcript expression of several inflammatory markers, including $I l 1 b$ and its downstream targets, are upregulated as early as 3 days in HFD-fed mice (40). That the upregulation of IL-1 $\beta$ contributes to acute islet compensation is supported by observations that Il1r1-deficient mice become glucose intolerant more rapidly following short-term HFD feeding compared with littermate controls. The glucose intolerance observed in these animals was attributed to $\beta$ cell dysfunction, as evidenced by an impaired insulin secretory response in Illr1-deficient mice. The role of IL-1 signaling in islet compensation was acute in nature, as the impairment in the in vivo insulin secretory response was no longer observed 30 days after HFD. While we cannot exclude an indirect role for IL-1 signaling in the compensatory response due to the use of whole-body Il1r1-KO mice, a direct action of IL-1 $\beta$ on insulin secretion is supported by the in vitro studies. The role of inflammatory responses in mediating $\beta$ cell compensation was further confirmed in an acute model of inflammation. The robust increase in plasma insulin following glucose injection characteristic of LPS administration was absent in mice deficient in Il1r1, consistent with the acute insulinotropic effects of IL-1 $\beta$ observed in vitro and with reported correlations between IL-1 $\beta$ concentrations and insulin secretion in vivo (62).

While the ability of IL-1 $\beta$ to directly enhance glucose-stimulated insulin secretion from pancreatic islets was reported almost 3 decades ago (25), the mechanisms underlying this phenomenon remain unclear (3739). Elevated concentrations of IL-1 $\beta$ are known to rapidly enhance insulin secretion induced by glucose $(25,39)$, sulfonylureas (34), or potassium chloride (38) in a stimulus-dependent manner (25) without affecting insulin content (38). While the insulinotropic effects of IL-1 $\beta$ require extracellular $\mathrm{Ca}^{2+}(31)$, IL- $1 \beta$ did not increase $\left[\mathrm{Ca}^{2+}\right]_{i}$ or $\mathrm{Ca}^{2+}$ currents, confirming that the site of IL-1 $\beta$ action is downstream of $\mathrm{Ca}^{2+}$ entry $(29,30,34)$. These findings indicate that the insulinotropic effects of IL-1 $\beta$ are independent of its previously reported effects on proliferation (17) and glucose metabolism (31) and are not due to unregulated $\beta$ cell lysis.

A modest depolymerization of cortical F-actin following exposure to IL-1 $\beta$ in both mouse and human $\beta$ cells was observed, suggesting that IL-1 $\beta$ potentiates stimulus-induced insulin secretion in part by inducing the depolymerization of F-actin. IL-1 $\beta$, however, also enhanced glucose-stimulated insulin secretion in the presence of complete F-actin depolymerization, demonstrating the ability of IL-1 $\beta$ to potentiate insulin secretion through an F-actin depolymerization-independent pathway. Time differences in responses to IL-1 $\beta$-induced potentiation of cortical F-actin depolymerization between human and mouse islets were observed. While these differences may be due to the use of recombinant human - rather than murine IL-1 $\beta$, the idea that mechanistic differences may also underlie these differences in cortical F-actin depolymerization is evidenced by findings that recombinant human IL-1 $\beta$ induces effects on granule trafficking and exocytosis within 30 minutes in mouse $\beta$ cells. Acute treatment with IL-1 $\beta$ was found to enhance granule density within $200 \mathrm{~nm}$ of the plasma membrane and increase SNARE complex formation in vitro. Consistent with IL-1 $\beta$-induced stimulation of granular protein exocytosis from human neutrophils (63), these morphological and molecular observations of granule docking resulted in functional effects, where IL-1 $\beta$ was found to acutely enhance pancreatic $\beta$ cell exocytosis.

Recently, the IL-1 $\beta$-induced remodeling of focal adhesions (FA) was associated with the insulinotropic actions of IL-1 $\beta$ (38). FA proteins function to integrate the extracellular matrix with cytoskeletal proteins and are known regulators of $\beta$ cell actin remodeling and insulin secretion $(38,52,64)$. In addition to their roles in cytoskeletal rearrangement, FA proteins have been implicated as regulators of SNARE complex formation with F-actin (64). The effects of IL-1 $\beta$ on both actin and exocytotic complex formation are supportive of FA proteins as regulators of the insulinotropic effect of IL-1 $\beta$. However, latrunculin B inhibits the glucose-induced activation of the FA proteins FA kinase and paxillin (64). That IL-1 $\beta$ potentiates insulin secretion in the presence of latrunculin B suggests an FA-independent pathway of IL-1 $\beta$ potentiation. While the molecular mechanisms underlying the insulinotropic effect of IL-1 $\beta$ remain unclear, the present study demonstrates that 
the potentiation of glucose-stimulated insulin secretion by IL-1 $\beta$ is mediated by distal effects on the stimulus-secretion coupling pathway, resulting in increased insulin granule docking and exocytosis.

Thus, we propose that IL-1 signaling contributes to islet compensation to acute metabolic stress by enhancing insulin secretory function, where IL-1 $\beta$ acts directly on $\beta$ cells to increase insulin secretion subsequent to increased granule trafficking and SNARE complex formation. A compensatory role for IL-1 signaling is further supported by findings that islets from obese donors are sensitized to the stimulatory effects of IL-1 $\beta$, whereas the insulinotropic effects of IL-1 $\beta$ are absent in obese T2D islets. This study highlights a positive role of IL-1 signaling in glucose homeostasis by mediating an enhancement of glucose-stimulated insulin secretion early in response to metabolic stress in mice and in islets from obese, but nondiabetic, humans.

\section{Methods}

Supplemental Methods are available online with this article.

Cells and cell culture. Islets from male C57BL/6 or transgenic mice were isolated by collagenase digestion and cultured in RPMI 1640 containing $11.1 \mathrm{mmol} / 1$ glucose with 10\% FBS and $100 \mathrm{U} / \mathrm{ml}$ of penicillin/streptomycin. Human islets were isolated from donor pancreata at the Alberta Diabetes Institute IsletCore (http://www.bcell.org/IsletCore.html) at the University of Alberta (Edmonton, Alberta, Canada) or the Clinical Islet Laboratory at the University of Alberta and were cultured in low-glucose $(5.5 \mathrm{mmol} / \mathrm{l})$ DMEM with L-glutamine, $110 \mathrm{mg} / 1$ sodium pyruvate, $10 \% \mathrm{FBS}$, and 100 units/ml penicillin/streptomycin. In total, islets from 22 human donors were examined in this study (age: $52.6 \pm 2.8$ years; BMI: $29 \pm 1.4$ $\mathrm{kg} / \mathrm{m}^{2} ; \mathrm{HbA}_{1 \mathrm{c}}: 5.8 \pm 0.16$ ), of which 3 were considered diabetic as determined by patient clinical history (Supplemental Table 1). For single cell experiments, human or mouse islets were dispersed by shaking in cell dissociation buffer (Gibco, Thermo Scientific) and plated in 35-mm culture dishes. INS 832/13 cells (from C. Newgard, Duke University, Durham, North Carolina, USA) were cultured in RPMI 1640 containing $11.1 \mathrm{mmol} / 1$ glucose with 10\% FBS, $10 \mathrm{mmol} / 1 \mathrm{HEPES}, 0.29 \mathrm{mg} / \mathrm{ml} \mathrm{L}$-glutamine, $1 \mathrm{mmol} / 1$ sodium pyruvate, $50 \mu \mathrm{l} \beta$-mercaptoethanol, and $100 \mathrm{U} / \mathrm{ml}$ of penicillin/streptomycin. Islets, INS 832/13 cells, or dispersed cells were cultured at $37^{\circ} \mathrm{C}$ and $5 \% \mathrm{CO}_{2}$.

Insulin secretion assay. Measurements were performed at $37^{\circ} \mathrm{C}$ in Krebs-Ringer Bicarbonate (KRB) solution containing (in mmol/1): $115 \mathrm{NaCl}, 5 \mathrm{KCl}, 24 \mathrm{NaHCO}_{3}, 2.5 \mathrm{CaCl}_{2}, 1 \mathrm{MgCl}_{2}, 10 \mathrm{HEPES}$, and $0.1 \%$ BSA ( $\mathrm{pH}$ 7.4). Intact mouse or human islets were preincubated for 2 hours in either 2.8 or $1.0 \mathrm{mmol} / 1$ glucose-KRB, respectively. Islets were transferred to fresh $\mathrm{KRB}$ solution containing 2.8 or $1.0 \mathrm{mmol} / 1 \mathrm{glu}$ cose for 1 hour, followed by incubation for 1 hour in $16.7 \mathrm{mmol} / 1$ glucose-KRB. Supernatant fractions were collected, and islets or cells were lysed in buffer containing $1.5 \%$ concentrated hydrochloric acid, $23.5 \%$ acetic acid, and $75 \%$ ethanol for assay of insulin content. Samples were stored at $-20^{\circ} \mathrm{C}$ and assayed for insulin via insulin detection kits (Meso Scale Discovery). Unless otherwise indicated, intact mouse and human islets were treated with IL-1 $\beta$ (10 ng/ml; Sigma-Aldrich) for 4 hours or 1 hour, respectively, due to differences in responses observed between species (Figure 1, A and B). Latrunculin B (10 $\mu$ mol/1; Sigma-Aldrich) was added to high-glucose stimulation, as indicated (Figure 3, C and D); in human islet experiments, IL-1 $\beta$ was added 1 hour prior and in addition to latrunculin B treatment (Figure 3D).

$\left[\mathrm{Ca}^{2+}\right]_{i}$ measurements. Prior to recordings, intact mouse islets were pretreated for 4 hours with vehicle

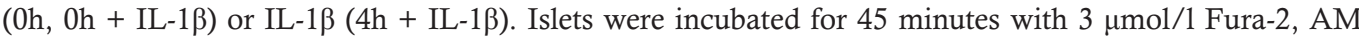
(Invitrogen) and $0.06 \%$ pluronic acid (Invitrogen) in solution containing (in mmol/1): $130 \mathrm{NaCl}, 5 \mathrm{KCl}, 2$ $\mathrm{CaCl}_{2}, 1 \mathrm{MgCl}_{2}, 5 \mathrm{NaHCO}_{3}$, and 10 HEPES ( $\mathrm{pH}$ 7.4) in the presence of vehicle (0h, $0 \mathrm{~h}+\mathrm{IL}-1 \beta$ ) or IL-1 $\beta$ $(4 \mathrm{~h}+\mathrm{IL}-1 \beta)$. Islets were imaged in $0.5 \mathrm{mmol} / 1$ glucose at $37^{\circ} \mathrm{C}$ with constant bath perfusion. Glucose was increased to $11 \mathrm{mmol} / 1$, and IL-1 $\beta$ was added $(0 \mathrm{~h}+\mathrm{IL}-1 \beta, 4 \mathrm{~h}+\mathrm{IL}-1 \beta)$. Imaging was performed with a Stallion Imaging System (Olympus) and acquired with Ratio Cam software (Metamorph; Molecular Devices). Excitation was at 340 and $380 \mathrm{~nm}$, and emission was collected using $510 \mathrm{~nm}$ bandpass filter (Semrock). The glucose-stimulated $\left[\mathrm{Ca}^{2+}\right]_{\mathrm{i}}$ response (GSCa) was calculated as the fold increase in the Fura-2 ratio following $11 \mathrm{mmol} / 1$ glucose versus the ratio at $0.5 \mathrm{mmol} / 1$ glucose.

Electrophysiology. Dispersed mouse islets were plated in $35-\mathrm{mm}$ culture dishes. Prior to electrophysiological recordings, cells were incubated in RPMI 1640 media with $2.8 \mathrm{mmol} / 1$ glucose for 1 hour. Solutions used for capacitance measurements are previously described (65). Vehicle or human recombinant IL-1 $\beta$ $(10 \mathrm{ng} / \mathrm{ml})$ were added to the extracellular bath solution for the duration of the recordings. Cells were patched following a 15- to 60-minute treatment with vehicle or IL-1 $\beta$. The standard whole cell technique with the sine+DC lockin function of an EPC10 amplifier and Patchmaster software (HEKA Electronics, 
Lambrecht/Pfalz) was used. Experiments were performed at $32^{\circ} \mathrm{C}-35^{\circ} \mathrm{C}$. The $\mathrm{Ca}^{2+}$ charge entry was calculated as the area under the curve of the $\mathrm{Ca}^{2+}$ current upon a single $500 \mathrm{~ms}$ depolarization from -70 to 0 $\mathrm{mV}$ normalized to cell size.

Actin staining. Dispersed human or mouse islets were plated onto untreated coverslips. Human and mouse cells were preincubated with 1.0 or $2.8 \mathrm{mmol} / 1 \mathrm{KRB}$ for 2 hours prior to treatment, respectively. Dispersed cells were treated with vehicle or human recombinant IL-1 $\beta(10 \mathrm{ng} / \mathrm{ml})$ in 1.0 or $2.8 \mathrm{mmol} / 1$ glucose-KRB, as indicated. To prevent any adverse effects of prolonged incubation at low glucose, 4-hour treatments of mouse cells were initiated 2 hours prior to, and maintained throughout, preincubation. Immediately following treatments, cells were fixed in 10\% Shandon Zinc Formal-Fixx (Thermo Scientific). Cells were stained for insulin with rabbit anti-insulin primary antibody (sc-9168, 1:200; Santa Cruz Biotechnology Inc.), followed by an anti-rabbit Alexa Fluor 594 (A11037, 1:200; Molecular Probes) and stained for F-actin with Alexa Fluor 488-conjugated phalloidin (A12379; Molecular Probes). Coverslips were mounted using ProLong Gold Antifade Reagent (Molecular Probes). Visualization was on a Perkin Elmer UltraView ERS spinning disk confocal (PerkinElmer) using a 40×/1.3 oil immersion objective. Fluorophores were stimulated using $488 \mathrm{~nm}$ (phalloidin) and $561 \mathrm{~nm}$ (insulin), and images were recorded on a Hamamatsu 9100 EMCCD with lateral resolution of $0.2 \mu \mathrm{m} /$ pixel. Images were acquired using Volocity software (PerkinElmer) and analyzed using ImageJ software (http://imagej.nih.gov/ij/). Four cross-section intensity measurements of F-actin were obtained and averaged for each cell. Only insulin-positive cells were analyzed.

Electron microscopy. Intact mouse islets were preincubated in $2.8 \mathrm{mmol} / 1 \mathrm{KRB}$ for 2 hours prior to treatment with human recombinant IL-1 $\beta(10 \mathrm{ng} / \mathrm{ml})$ or high glucose $(16.7 \mathrm{mmol} / 1)$, as indicated. Immediately following treatments, cells were fixed in a $2 \times$ fixative containing $4 \%$ glutaraldehyde, $0.2 \mathrm{~mol} / 1$ sucrose, and $4 \mathrm{mmol} / 1 \mathrm{CaCl}_{2}$ in $0.16 \mathrm{~mol} / 1$ sodium cacodylate buffer $(\mathrm{pH} 7.4$ ) and processed as previously described (66). Images were acquired using a Hitachi H-7650 transmission electron microscope equipped with a 16 megapixel EMCCD XR111 camera (Advanced Microscopy Techniques) and AMT version 600 imaging software (Advance Microscopy Techniques). Images were analyzed using ImageJ software (http://imagej. nih.gov/ij/).

Immunoblotting and immunoprecipitation. INS 832/13 cells were preincubated for 2 hours in $0 \mathrm{mmol} / 1$ glucose KRB and subsequently treated for 30 minutes with human recombinant IL-1 $\beta$ (10 ng/ml). Following treatment, cells were lysed in buffer containing (in mmol/1): 20 Tris- $\mathrm{HCl}$ ( $\mathrm{pH}$ 7.5), $150 \mathrm{NaCl}, 1$ EGTA, 1 EDTA, 1\% Triton X-100, and protease inhibitor cocktail (Set V; Millipore). For immunoprecipitation, 500-700 $\mu \mathrm{g}$ of total cell lysates were incubated with $2 \mu \mathrm{g}$ of normal mouse IgG (sc-2025; Santa Cruz Biotechnology Inc.) or mouse anti-syntaxin-1 (sc-73098; Santa Cruz Biotechnology Inc.) and $30 \mu 1$ of 50\% protein G slurry (GE Life Sciences) overnight at $4^{\circ} \mathrm{C}$. Immunoprecipitates were washed 5 times with lysis buffer. These or whole cell lysates were separated using SDS-PAGE, transferred to polyvinylidene difluoride membranes (Millipore), probed with primary antibodies (anti-SNAP-25 [5308S, 1:1000; Cell Signaling Technology]; anti-syntaxin-1 [sc-73098, 1:1000; Santa Cruz Biotechnology Inc.]) and detected with appropriate peroxidase-conjugated secondary antibodies (Amersham, Baie d'Urfe, PQ). Images were acquired using a ChemiDoc MP System (Bio-Rad) and analyzed using Image Lab Software 5.2.1 (Bio-Rad).

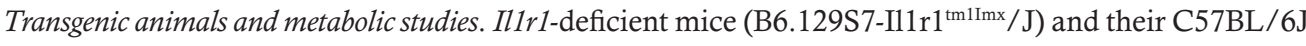
controls were purchased from The Jackson Laboratory. Experiments were conducted on male littermates between 10-14 weeks of age, unless otherwise indicated. Genotypes were determined using primers (Neo-R cassette forward 5'-CTGAATGAACTGCAGGACGAGGCAG-3'; reverse 5'-GGCCACAGTCGATGAATCCA GAAAAGC-3'. IL-1 receptor forward 5'-ATTTCAGCATGTGTTTCCACACTCCCTCA-3'; reverse 5'-TACGCCCTCCCACTTGAACAACTTATTTGG-3') and the REDE-N-Amp tissue PCR kit (Sigma-Aldrich) on ear notches (Supplemental Figure 1A). Where indicated, mice were fed a HFD (60\% kcal from fat, F3283; Bio-Serv) for 2, 9, or 30 days or were given an i.p. injection of either $2 \mathrm{mg} / \mathrm{kg}$ LPS (Sigma-Aldrich) or vehicle control (PBS) 6 hours prior to metabolic studies. Glucose tolerance tests were performed on animals fasted for 3 or 6 hours, as indicated in figure legends, by i.p. injection of dextrose (1 $\mathrm{g} / \mathrm{kg}$ ). Blood was collected at times indicated, assayed for glucose using a glucose meter (OneTouch), and stored in Microvette $100 \mathrm{Li}$ Heparin (Sarstedt) tubes. Samples were centrifuged at $4^{\circ} \mathrm{C}$ for 10 minutes at $9,330 \mathrm{~g}$, and supernatant was collected and assayed for insulin using Insulin Detection Kits (Meso Scale Discovery). Insulin tolerance tests were performed on mice fasted for 3 or 6 hours, as indicated in figure legends, by i.p. injection of $1 \mathrm{U} / \mathrm{kg}$ Humulin R (Lilly). 
Statistics. Data were analyzed using FitMaster (HEKA Electronik) or GraphPad Prism (v6.0c) and were compared by unpaired Student's $t$ test or by 1-, 2-way, or repeated-measures ANOVA followed by a post hoc $t$ test using the Tukey or Sidak method, as indicated in figure legends. Outliers were identified and removed using Grubbs' test for outliers except for one animal that was removed from data set in Figure $5 \mathrm{~A}$, as its body weight differed by greater than $10 \%$ of the group mean. Associations between variables were analyzed using Pearson correlation coefficients, and lines of best fit were obtained through linear regression. Data are expressed as means \pm SEM, where $P<0.05$ is considered significant.

Study approval. The animal care and use committee (AUP00000405, AUP00000291) and the human research ethics board (Pro00001754) at the University of Alberta approved all studies. All families of organ donors provided informed consent for use of pancreatic tissue in research.

\section{Author contributions}

$\mathrm{NS}, \mathrm{AFS}, \mathrm{XD}, \mathrm{LS}$, and $\mathrm{AB}$ researched data. MF and PEM contributed to discussion and reviewed and edited the manuscript. $\mathrm{CH}$ researched and analyzed data, contributed to discussion, and wrote the manuscript. PEM takes full responsibility for the work as a whole, including the study design, access to data, and the decision to submit and publish the manuscript.

\section{Acknowledgments}

The authors are grateful to Chris Newgard (Duke University) for INS-1 832/13 cells and to James Shapiro and Tatsuya Kin at the Clinical Islet Laboratory (University of Alberta) and James Lyon at the Alberta Diabetes Institute Human IsletCore (University of Alberta) for the isolation of human islets. The authors would also like to thank the Human Organ Procurement and Exchange program, the Trillium Gift of Life Network (TGLN), and the Alberta Diabetes Foundation for their efforts in procuring human pancreases and funding human islet isolations for research. Funding was provided to P.E. MacDonald as an Operating Grant from the Canadian Diabetes Association (OG-3-14-4565-PM). C. Hajmrle is supported by studentships from Alberta Innovates Health Solutions and Canadian Institutes of Health Research. L. Senior was supported by a summer studentship from the Alberta Diabetes Institute. P.E. MacDonald hold the Canada Research Chair in Islet Biology.

Address correspondence to: Patrick MacDonald, University of Alberta, Li Ka Shing Centre, Rm. 6-126, Edmonton, AB, Canada, T6G 2E1. Phone: 780.492.8063; E-mail: pmacdonald@ualberta.ca.

1. Kahn SE, Cooper ME, Del Prato S. Pathophysiology and treatment of type 2 diabetes: perspectives on the past, present, and future. Lancet. 2014;383(9922):1068-1083.

2. Donath MY, Shoelson SE. Type 2 diabetes as an inflammatory disease. Nat Rev Immunol. 2011;11(2):98-107.

3. Sauter NS, Schulthess FT, Galasso R, Castellani LW, Maedler K. The antiinflammatory cytokine interleukin-1 receptor antagonist protects from high-fat diet-induced hyperglycemia. Endocrinology. 2008;149(5):2208-2218.

4. Maedler K, et al. Glucose-induced $\beta$ cell production of IL-1 $\beta$ contributes to glucotoxicity in human pancreatic islets. JClin Invest. 2002;110(6):851-860.

5. Böni-Schnetzler M, et al. Increased interleukin (IL)-1 $\beta$ messenger ribonucleic acid expression in $\beta$-cells of individuals with type 2 diabetes and regulation of IL-1 $\beta$ in human islets by glucose and autostimulation. J Clin Endocrinol Metab. 2008;93(10):4065-4074

6. Rabinovitch A, Sumoski W, Rajotte RV, Warnock GL. Cytotoxic effects of cytokines on human pancreatic islet cells in monolayer culture. J Clin Endocrinol Metab. 1990;71(1):152-156.

7. Spranger J, et al. Inflammatory cytokines and the risk to develop type 2 diabetes: results of the prospective population-based European Prospective Investigation into Cancer and Nutrition (EPIC)-Potsdam Study. Diabetes. 2003;52(3):812-817.

8. Interleukin 1 Genetics Consortium. Cardiometabolic effects of genetic upregulation of the interleukin 1 receptor antagonist: a Mendelian randomisation analysis. Lancet Diabetes Endocrinol. 2015;3(4):243-253.

9. Ridker PM, et al. Effects of interleukin-1 $\beta$ inhibition with canakinumab on hemoglobin A1c, lipids, C-reactive protein, interleukin-6, and fibrinogen: a phase IIb randomized, placebo-controlled trial. Circulation. 2012;126(23):2739-2748.

10. van Asseldonk EJP, et al. Treatment with Anakinra improves disposition index but not insulin sensitivity in nondiabetic subjects with the metabolic syndrome: a randomized, double-blind, placebo-controlled study. J Clin Endocrinol Metab. 2011;96(7):2119-2126.

11. Rissanen A, Howard CP, Botha J, Thuren T, Global Investigators. Effect of anti-IL-1 $\beta$ antibody (canakinumab) on insulin secretion rates in impaired glucose tolerance or type 2 diabetes: results of a randomized, placebo-controlled trial. Diabetes Obes Metab. 2012;14(12):1088-1096.

12. Larsen CM, et al. Interleukin-1-receptor antagonist in type 2 diabetes mellitus. N Engl J Med. 2007;356(15):1517-1526.

13. Cavelti-Weder C, et al. Effects of gevokizumab on glycemia and inflammatory markers in type 2 diabetes. Diabetes Care. 2012;35(8):1654-1662.

14. Sloan-Lancaster J, et al. Double-blind, randomized study evaluating the glycemic and anti-inflammatory effects of subcutaneous 
LY2189102, a neutralizing IL-1 $\beta$ antibody, in patients with type 2 diabetes. Diabetes Care. 2013;36(8):2239-2246.

15. van Poppel PC, et al. The interleukin-1 receptor antagonist anakinra improves first-phase insulin secretion and insulinogenic index in subjects with impaired glucose tolerance. Diabetes Obes Metab. 2014;16(12):1269-1273.

16. García MC, et al. Mature-onset obesity in interleukin-1 receptor I knockout mice. Diabetes. 2006;55(5):1205-1213.

17. Maedler K, et al. Low concentration of interleukin-1beta induces FLICE-inhibitory protein-mediated $\beta$-cell proliferation in human pancreatic islets. Diabetes. 2006;55(10):2713-2722.

18. Oguri S, Motegi K, Iwakura Y, Endo Y. Primary role of interleukin-1 $\alpha$ and interleukin-1 $\beta$ in lipopolysaccharide-induced hypoglycemia in mice. Clin Diagn Lab Immunol. 2002;9(6):1307-1312.

19. Besedovsky H, del Rey A. Neuroendocrine and metabolic responses induced by interleukin-1. J Neurosci Res. 1987;18(1):172-178.

20. del Rey A, Besedovsky H. Interleukin 1 affects glucose homeostasis. Am J Physiol. 1987;253(5 pt 2):R794-R798.

21. Cornell RP. Hyperinsulinemia elicited by interleukin-1 and nonlethal endotoxemia in rats. Circ Shock. 1989;28(2):121-130.

22. Ling PR, Istfan NW, Colon E, Bistrian BR. Differential effects of interleukin-1 receptor antagonist in cytokine- and endotoxin-treated rats. Am J Physiol. 1995;268(2 pt 1):E255-E261.

23. Yelich MR. Effects of endotoxin and interleukin-1 on glucagon and insulin secretion from the perfused rat pancreas. Pancreas. 1992;7(3):358-366.

24. Yelich MR. In vivo endotoxin and IL-1 potentiate insulin secretion in pancreatic islets. Am J Physiol. 1990;258(4 pt 2):R1070-R1077.

25. Zawalich WS, Diaz VA. Interleukin 1 inhibits insulin secretion from isolated perifused rat islets. Diabetes. 1986;35(10):1119-1123

26. Comens PG, Wolf BA, Unanue ER, Lacy PE, McDaniel ML. Interleukin 1 is potent modulator of insulin secretion from isolated rat islets of Langerhans. Diabetes. 1987;36(8):963-970.

27. Zawalich WS, Zawalich KC. Interleukin 1 is a potent stimulator of islet insulin secretion and phosphoinositide hydrolysis. Am J Physiol. 1989;256(1 pt 1):E19-E24.

28. Palmer JP, et al. Interaction of $\beta$-cell activity and IL-1 concentration and exposure time in isolated rat islets of Langerhans. Diabetes. 1989;38(10):1211-1216.

29. Helqvist S, Bouchelouche P, Andersen HU, Nerup J. Modulation of calcium flux influences interleukin $1 \beta$ effects on insulin release from isolated islets of Langerhans. Acta Endocrinol. 1989;121(3):447-455

30. Welsh $\mathrm{N}$, et al. Human interleukin $1 \beta$ stimulates islet insulin release by a mechanism not dependent on changes in phospholipase $\mathrm{C}$ and protein kinase $\mathrm{C}$ activities or $\mathrm{Ca}^{2+}$ handling. Acta Endocrinol. 1989;121(5):698-704.

31. Eizirik DL, Sandler S. Human interleukin-1 $\beta$ induced stimulation of insulin release from rat pancreatic islets is accompanied by an increase in mitochondrial oxidative events. Diabetologia. 1989;32(11):769-773.

32. Borg LA, Eizirik DL. Short-term exposure of rat pancreatic islets to human interleukin-1 $\beta$ increases cellular uptake of calcium. Immunol Lett. 1990;26(3):253-258.

33. Welsh N, Bendtzen K, Sandler S. Influence of protease on inhibitory and stimulatory effects of interleukin $1 \beta$ on $\beta$-cell function. Diabetes. 1991;40(2):290-294.

34. Eizirik DL, Sandler S, Welsh N, Juntti-Berggren L, Berggren PO. Interleukin-1 $\beta$-induced stimulation of insulin release in mouse pancreatic islets is related to diacylglycerol production and protein kinase C activation. Mol Cell Endocrinol. 1995;111(2):159-165.

35. Eizirik DL, Welsh N, Hellerström C. Predominance of stimulatory effects of interleukin-1 beta on isolated human pancreatic islets. J Clin Endocrinol Metab. 1993;76(2):399-403.

36. Eizirik DL, Tracey DE, Bendtzen K, Sandler S. Role of receptor binding and gene transcription for both the stimulatory and inhibitory effects of interleukin-1 in pancreatic beta-cells. Autoimmunity. 1992;12(2):127-133.

37. Jeong IK, et al. The stimulatory effect of IL-1beta on the insulin secretion of rat pancreatic islet is not related with iNOS pathway. Exp Mol Med. 2002;34(1):12-17.

38. Arous C, Ferreira PG, Dermitzakis ET, Halban PA. Short term exposure of $\beta$ cells to low concentrations of interleukin-1 $\beta$ improves insulin secretion through focal adhesion and actin remodeling and regulation of gene expression. J Biol Chem. 2015;290(10):6653-6669.

39. McDaniel ML, Hughes JH, Wolf BA, Easom RA, Turk JW. Descriptive and mechanistic considerations of interleukin 1 and insulin secretion. Diabetes. 1988;37(10):1311-1315.

40. Lee YS, et al. Inflammation is necessary for long-term but not short-term high-fat diet-induced insulin resistance. Diabetes. 2011;60(10):2474-2483.

41. de Vries MA, et al. Postprandial inflammation: targeting glucose and lipids. Adv Exp Med Biol. 2014;824:161-170.

42. Sage AT, et al. Metabolic syndrome and acute hyperglycemia are associated with endoplasmic reticulum stress in human mononuclear cells. Obesity (Silver Spring). 2012;20(4):748-755

43. van Oostrom AJ, et al. Postprandial recruitment of neutrophils may contribute to endothelial dysfunction. J Lipid Res. 2003;44(3):576-583.

44. Esposito K, et al. Inflammatory cytokine concentrations are acutely increased by hyperglycemia in humans: role of oxidative stress. Circulation. 2002;106(16):2067-2072.

45. Böni-Schnetzler M, et al. Free fatty acids induce a proinflammatory response in islets via the abundantly expressed interleukin-1 receptor I. Endocrinology. 2009;150(12):5218-5229.

46. Dula SB, et al. Evidence that low-grade systemic inflammation can induce islet dysfunction as measured by impaired calcium handling. Cell Calcium. 2010;48(2-3):133-142.

47. Thurmond DC, Gonelle-Gispert C, Furukawa M, Halban PA, Pessin JE. Glucose-stimulated insulin secretion is coupled to the interaction of actin with the t-SNARE (target membrane soluble N-ethylmaleimide-sensitive factor attachment protein receptor protein) complex. Mol Endocrinol. 2003;17(4):732-742.

48. Kalwat MA, Thurmond DC. Signaling mechanisms of glucose-induced F-actin remodeling in pancreatic islet $\beta$ cells. Exp Mol Med. 2013;45:e37.

49. Gaisano HY. Here come the newcomer granules, better late than never. Trends Endocrinol Metab. 2014;25(8):381-388

50. Kasai K, et al. Rab27a mediates the tight docking of insulin granules onto the plasma membrane during glucose stimulation. J Clin Invest. 2005;115(2):388-396. 
51. Gomi H, Mizutani S, Kasai K, Itohara S, Izumi T. Granuphilin molecularly docks insulin granules to the fusion machinery. J Cell Biol. 2005;171(1):99-109.

52. Cai EP, et al. In vivo role of focal adhesion kinase in regulating pancreatic $\beta$-cell mass and function through insulin signaling, actin dynamics, and granule trafficking. Diabetes. 2012;61(7):1708-1718.

53. Prentki M, Nolan CJ. Islet $\beta$ cell failure in type 2 diabetes. J Clin Invest. 2006;116(7):1802-1812.

54. Mosser RE, et al. High-fat diet-induced $\beta$-cell proliferation occurs prior to insulin resistance in C57B1/6J male mice. Am J Physiol Endocrinol Metab. 2015;308(7):E573-E582.

55. Lackey DE, Olefsky JM. Regulation of metabolism by the innate immune system. Nat Rev Endocrinol. 2016;12(1):15-28

56. Dinarello CA. IL-1: discoveries, controversies and future directions. Eur J Immunol. 2010;40(3):599-606.

57. Butler AE et al. $\beta$-Cell deficit and increased $\beta$-cell apoptosis in humans with type 2 diabetes. Diabetes. 2003;52(1):102-110.

58. Gonzalez A, et al. Insulin hypersecretion in islets from diet-induced hyperinsulinemic obese female mice is associated with several functional adaptations in individual $\beta$-cells. Endocrinology. 2013;154(10):3515-3524.

59. Nolan CJ, et al. $\beta$ Cell compensation for insulin resistance in Zucker fatty rats: increased lipolysis and fatty acid signalling. Diabetologia. 2006;49(9):2120-2130.

60. Misaki Y, et al. Plasma interleukin-1 $\beta$ concentrations are closely associated with fasting blood glucose levels in healthy and preclinical middle-aged nonoverweight and overweight Japanese men. Metab Clin Exp. 2010;59(10):1465-1471.

61. El-Wakkad A, Hassan NE-M, Sibaii H, El-Zayat SR. Proinflammatory, anti-inflammatory cytokines and adiponkines in students with central obesity. Cytokine. 2013;61(2):682-687.

62. Bissonnette S, et al. Plasma IL-1Ra: linking hyperapoB to risk factors for type 2 diabetes independent of obesity in humans. Nutr Diabetes. 2015;5:e180.

63. Smith RJ, Bowman BJ, Speziale SC. Interleukin-1 stimulates granule exocytosis from human neutrophils. Int J Immunopharmacol. 1986;8(1):33-40

64. Rondas D, Tomas A, Soto-Ribeiro M, Wehrle-Haller B, Halban PA. Novel mechanistic link between focal adhesion remodeling and glucose-stimulated insulin secretion. J Biol Chem. 2012;287(4):2423-2436.

65. Dai XQ, et al. SUMOylation regulates insulin exocytosis downstream of secretory granule docking in rodents and humans. Diabetes. 2011;60(3):838-847.

66. Cho WJ, Chow AK, Schulz R, Daniel EE. Matrix metalloproteinase-2, caveolins, focal adhesion kinase and c-Kit in cells of the mouse myocardium. J Cell Mol Med. 2007;11(5):1069-1086. 